\title{
Comparison of an avidin-biotin immunoassay with three commercially available immunofluorescence kits for typing of herpes simplex virus
}

\author{
DL BARNARD, ${ }^{*}$ FB JOHNSON, ${ }^{*}$ DF RICHARDS $\dagger$ \\ From the ${ }^{*}$ Department of Microbiology, Brigham Young University, Provo, Utah; and $†$ Richards \\ Laboratories Inc, Utah, United States
}

SUMMARY An avidin-biotin complex system was compared with three commercially available immunofluorescence kits for serotyping herpes simplex virus isolates from clinical specimens Sensitivity values showed that the Electro-Nucleonics and Immulok reagents were useful in detecting the presence of virus, whereas the predictive values showed that the Syva and Immulok reagents possessed adequate discrimination between the herpes simplex virus serotypes. The avidin-biotin complex system was equal or superior to the immunofluorescence reagents tested both in detecting herpes simplex virus antigens in cell culture and in serotyping herpes simplex virus isolates.

Standard methods for detecting herpes simplex virus infections have been cytochemical staining, ${ }^{1}$ direct or indirect immunofluorescence, ${ }^{23}$ and tissue culture. ${ }^{4}$ The cytochemical tests are relatively insensitive and do not allow for typing of herpes simplex virus isolates. The immunofluorescence tests are routinely used by many laboratories and are comparatively sensitive and specific; they require, however, an expensive fluorescence microscope and are subject to difficulties in interpretation. Tissue culture isolation may be time consuming as many isolates may take up to five days or more to show cytopathic effects. Recently, there have been many reports that have used enzyme linked immunoassays (ELISA) to detect rapidly herpes simplex virus either directly from clinical specimens or in combination with tissue culture isolation. ${ }^{5-8}$ The sensitivity of ELISA systems has been enhanced by the use of fluorogenic substrates, ${ }^{9}$ chemoluminescence, ${ }^{10}$ and avidin-biotin systems. ${ }^{11} 12$ In addition, such relatively sophisticated methods as restriction endonuclease analysis ${ }^{13}$ and nucleic acid hybridisation ${ }^{14}$ have now been used successfully to detect herpes simplex virus infections. In combination with monoclonal antibodies, immunofluorescence and avidin-biotin systems can be used to serotype herpes simplex virus clinical isolates. The avidin-biotin system is based on the high affinity of avidin for biotin (affinity constant

Accepted for publication 22 May 1985 $\left.10^{15} / \mathrm{mol}\right) .{ }^{15}$ One molecule of avidin can bind fou molecules of biotin, and biotin can be covalentlo. linked to antibody without affecting the antige binding capacity. ${ }^{16}$ The sensitivity of this system has been further enhanced by binding avidin to three molecules of biotin that have been previously bound with horseradish peroxidase, forming what has been termed an avidin-biotin complex. ${ }^{17}$ The remaining binding site on the avidin molecule can then be bound to a biotinylated anti-immunoglobulin specific for antiherpes simplex virus antibody. The complex results in a more intensely stained immune reaction, which has been shown to enhance sensitivity in some detection systems. ${ }^{1819}$ In this study we compared the avidin-biotin complex staining method with that of three commercially available fluorescent antibody kits for serotyping herpes simplex virus clinical isolates.

\section{Material and methods}

\section{VIRUSES}

The herpes simplex virus strains, HSV 2, strain 333, $\mathrm{\omega}$ and HSV 1, strain McIntyre, were propagated in Vero and Flow 2000 cells, respectively. Herpes sim- $\stackrel{\varrho}{\simeq}$ plex virus clinical isolates were obtained primarily from urogenital sites. The isolates were provided by ${ }_{-}^{-}$ several clinics, hospitals, and private physicians in the western United States. The samples were col- $\overrightarrow{\mathbb{D}}$ lected and transported to a central laboratory for 
virological testing as previously described. ${ }^{20}$ All specimens were cultured on Vero cells and monitored for cytopathic effects for one week. The presence of herpes simplex virus in cultures showing positive cytopathic effects was confirmed by an immunoperoxidase assay. ${ }^{21}$ Fifty isolates confirmed as herpes simplex virus and the two laboratory strains were amplified in Vero cell culture, and the stocks made from these subcultures were stored at $-70^{\circ} \mathrm{C}$ until further testing.

CELLS AND MEDIA

All virus isolation from clinical specimens, as well as propagation, and viral testing was carried out in Vero cells. ${ }^{14}$ The cells were routinely grown in Dulbecco's modified Eagle's medium (Sigma, St Louis) supplemented with $0.11 \%$ sodium bicarbonate, $10 \%$ fetal bovine serum (Sterile Systems, Logan, Utah), 2 mmol HEPES (N-2-hydroxyethylpiperazine- $\mathrm{N}^{\prime}$-2-ethanesulphonic acid) buffer, and $50 \mu \mathrm{g}$ of gentamicin $/ \mathrm{ml}$.

SEROTYPING WITH THE COMMERCIAL

IMMUNOFLUORESCENCE KITS

Virus testing was carried out in Vero cells in flat sided tissue culture tubes. When testing an immunofluorescence kit, the tubes contained a glass coverslip $(11 \times 22 \mathrm{~mm})$. All tubes were incubated until a cytopathic effect was seen (24-48 hours) at $37^{\circ} \mathrm{C}$. The cells on the coverslips were fixed in cold acetone and tested with the appropriate typing system.

The herpes simplex virus typing systems used were from Syva Co, Palo Alto, Ca, United States (a direct immunofluorescence kit), Immulok Inc, Carpinteria, $\mathrm{Ca}$, United States (now Ortho), and Electro-Nucleonics Inc, Fairfield, NJ, United States (indirect immunofluorescence kits). The protocols outlined in the commercial kits were followed in all cases for testing the herpes simplex virus isolates. The monoclonal antibodies provided in the Immulok and Syva kits were type specific. The monoclonal antibodies provided with the ElectroNucleonics kit were directed against an antigen common to both HSV 1 and HSV 2, and also to an HSV 2 specific antigen. With this test a positive typed HSV 2 isolate reacted with either the HSV 2 specific monoclonal antibody alone or with both monoclonal antibodies $(++,-+)$. A positive HSV 1 isolate reacted only with the antibody to the common antigen (+-).

\section{AVIDIN-BIOTIN COMPLEX}

The staining reagents were obtained from Vector Laboratories, Burlingame, Ca, United States, HSV 1 specific monoclonal antibody from Capell Laboratories, West Chester, $\mathrm{Pa}$, United States, and HSV 2 specific monoclonal antibody from Biotech
Research Laboratories Inc, Rockville, Md, United States.

Isolates were inoculated into duplicate tubes, incubated at $37^{\circ} \mathrm{C}$ for 24 hours, and fixed in alcohol-formalin-acetic acid fixative. After fixation the tubes for each isolate were rinsed three times in distilled water, drained, and incubated with $0.5 \mathrm{ml}$ of the appropriate monoclonal antibody for 30 minutes at $37^{\circ} \mathrm{C}$. The tubes were then rinsed three times in distilled water, drained, and incubated with $0.5 \mathrm{ml}$ of biotinylated antimouse IgG at $37^{\circ} \mathrm{C}$ for 30 minutes. The tubes were rinsed again three times in distilled water, drained, and incubated with $0.5 \mathrm{ml}$ of avidin-biotin complex at $37^{\circ} \mathrm{C}$ for 30 minutes. The tubes were rinsed, drained and incubated for 30 minutes at $37^{\circ} \mathrm{C}$ with $2 \mathrm{ml}$ of 4-chloro-1-naphthol $(0.1 \mathrm{mg} / \mathrm{ml})$, to which $\mathrm{H}_{2} \mathrm{O}_{2}$ had been added to a final concentration of $0.003 \%$. Care was taken not to let the tubes dry out at any time during fixation or staining. The stained cell sheets were then examined microscopically under $200 \times$ magnification. The intensity of staining was scored according to a visual scale, which ranged from 0 to $4+$ staining. The presence of one or more stained foci of virus infection on a cell sheet was considered to be positive.

\section{Results}

Two laboratory strains and 50 clinical isolates were serotyped by the avidin-biotin complex method and three sets of immunofluorescence reagents (Table 1). Of the three immunofluorescence kits the Syva and Electro-Nucleonics reagents stained the herpes simplex virus antigens with the greatest intensity. Several isolates were not typable by the Syva and the Electro-Nucleonics kits because neither monoclonal HSV type specific antibody reacted with the herpes simplex virus antigens present in the infected cells. The opposite difficulty was encountered with the avidin-biotin complex and Immulok systems in that two isolates were stained with both type 1 and type 2 reagents. The negative controls, consisting of uninfected cells, were uniformly negative in the tests performed by all four methods. Table 2 shows the reaction patterns and numbers of isolates giving the pattern. There was relatively good agreement between the typing results of the avidin-biotin complex and Immulok methods and appreciably less agreement obtained by the Syva and Electro-Nucleonics methods. About $80 \%$ of the clinical isolates were type 2 strains. It is noteworthy that six strains were untypable with the Syva reagents because of no reaction with either monoclonal antibody provided in this kit.

The sensitivities of the three immunofluorescence kits for detecting herpes simplex virus antigens were 
Table 1 Comparative serotyping of herpes simplex virus (HSV) clinical isolates using an avidin-biotin complex (ABC) stain method and three commercial immunoftuorescence reagents

\begin{tabular}{|c|c|c|c|c|c|c|c|c|c|c|c|c|c|}
\hline \multirow[t]{2}{*}{ Virus } & \multicolumn{3}{|c|}{$A B C$ stain } & \multicolumn{3}{|c|}{ Immulok } & \multicolumn{3}{|l|}{ Syva } & \multicolumn{4}{|c|}{ Electro-Nucleonics } \\
\hline & $H S V 1$ & $H S V 2$ & Serotype & $H S V 1$ & $H S V 2$ & Serotype & $H S V 1$ & $H S V 2$ & Serotype & $\begin{array}{l}\text { Type } \\
\text { common }\end{array}$ & HSV 2 & Serotype & \\
\hline $\begin{array}{l}333 \\
\text { Mclntyre } \\
\text { A0077* } \\
\text { A0084 } \\
\text { A0095 }\end{array}$ & $\begin{array}{l}\overline{3+} \\
= \\
-\end{array}$ & $\begin{array}{l}4+ \\
\frac{4+}{4+} \\
3+ \\
3+\end{array}$ & $\begin{array}{l}2 \\
1 \\
2 \\
2 \\
2\end{array}$ & $\begin{array}{l}\overline{1+} \\
\overline{\operatorname{tr}}\end{array}$ & $\begin{array}{l}\frac{1+}{1+} \\
\mathrm{tr} \\
1+\end{array}$ & $\begin{array}{l}2 \\
1 \\
2 \\
2 \\
2\end{array}$ & $\begin{array}{l}\overline{3+} \\
\frac{-}{\operatorname{tr}}\end{array}$ & $\frac{\frac{3+}{2+}}{\frac{2+}{2+}}$ & $\begin{array}{l}2 \\
1 \\
2 \\
+ \\
2\end{array}$ & $\begin{array}{l}4+ \\
4+ \\
\overline{2+} \\
2+\end{array}$ & $\begin{array}{l}\frac{4+}{1+} \\
2+ \\
-\end{array}$ & $\begin{array}{l}2 \\
1 \\
2 \\
2 \\
1\end{array}$ & \\
\hline $\begin{array}{l}\text { A0114 } \\
\text { A0131 } \\
\text { A0137 } \\
\text { A0159 } \\
\text { A0160 }\end{array}$ & $\begin{array}{l}2+ \\
= \\
=\end{array}$ & $\begin{array}{l}\text { tr } \\
3+ \\
3+ \\
2+ \\
3+\end{array}$ & $\begin{array}{l}1 \\
2 \\
2 \\
2 \\
2\end{array}$ & $\begin{array}{l}2+ \\
= \\
-\end{array}$ & $\begin{array}{l}\overline{1+} \\
\text { tr } \\
1+ \\
2+\end{array}$ & $\begin{array}{l}1 \\
2 \\
2 \\
2 \\
2\end{array}$ & $\begin{array}{l}3+ \\
= \\
=\end{array}$ & $\begin{array}{l}\overline{2+} \\
\overline{3+} \\
2+\end{array}$ & $\begin{array}{l}1 \\
2 \\
\dagger \\
2 \\
2\end{array}$ & $\begin{array}{l}3+ \\
\frac{1+}{2+} \\
2+\end{array}$ & $\begin{array}{l}\overline{4+} \\
2+ \\
4+ \\
-\end{array}$ & $\begin{array}{l}1 \\
2 \\
2 \\
2 \\
1\end{array}$ & \\
\hline $\begin{array}{l}\text { A0168 } \\
\text { A0192 } \\
\text { A0196 } \\
\text { A0203 } \\
\text { A0216 }\end{array}$ & $\begin{array}{l}\bar{z} \\
\bar{z} \\
-\end{array}$ & $\begin{array}{l}3+ \\
3+ \\
3+ \\
3+ \\
4+\end{array}$ & $\begin{array}{l}2 \\
2 \\
2 \\
2 \\
2\end{array}$ & $\begin{array}{l}\bar{z} \\
\bar{z}\end{array}$ & $\begin{array}{l}1+ \\
1+ \\
1+ \\
1+ \\
1+\end{array}$ & $\begin{array}{l}2 \\
2 \\
2 \\
2 \\
2\end{array}$ & $\begin{array}{l}\overline{\mathrm{NT}} \\
\overline{-} \\
-\end{array}$ & $\begin{array}{l}3+ \\
\text { NT } \\
2+ \\
3+ \\
3+\end{array}$ & $\begin{array}{l}\frac{2}{2} \\
2 \\
2\end{array}$ & $\begin{array}{l}3+ \\
1+ \\
1+ \\
3+\end{array}$ & $\begin{array}{l}\overline{4+} \\
4+ \\
4+ \\
4+\end{array}$ & $\begin{array}{l}1 \\
2 \\
2 \\
2 \\
2\end{array}$ & \\
\hline $\begin{array}{l}\text { A0218 } \\
\text { A0226 } \\
\text { A0227 } \\
\text { A0232 } \\
\text { A0234 }\end{array}$ & $\begin{array}{l}z \\
z \\
-\end{array}$ & $\begin{array}{l}4+ \\
2+ \\
3+ \\
3+ \\
4+\end{array}$ & $\begin{array}{l}2 \\
2 \\
2 \\
2 \\
2\end{array}$ & $\begin{array}{l}z \\
\bar{z} \\
-\end{array}$ & $\begin{array}{l}1+ \\
2+ \\
2+ \\
2+ \\
1+\end{array}$ & $\begin{array}{l}2 \\
2 \\
2 \\
2 \\
2\end{array}$ & $\begin{array}{l}z \\
z \\
-\end{array}$ & $\begin{array}{l}2+ \\
2+ \\
3+ \\
\frac{2+}{2+}\end{array}$ & $\begin{array}{l}2 \\
2 \\
2 \\
+ \\
2\end{array}$ & $\begin{array}{l}\overline{3+} \\
4+ \\
1+ \\
4+\end{array}$ & $\begin{array}{l}4+ \\
2+ \\
2+ \\
1+ \\
-\end{array}$ & $\begin{array}{l}2 \\
2 \\
2 \\
2 \\
1\end{array}$ & \\
\hline $\begin{array}{l}\text { A0260 } \\
\text { A0261 } \\
\text { A0270 } \\
\text { A0285 } \\
\text { A0286 }\end{array}$ & $\begin{array}{l}\overline{-} \\
\frac{2}{2+}\end{array}$ & $\begin{array}{l}3+ \\
4+ \\
2+ \\
1+ \\
3+\end{array}$ & $\begin{array}{l}2 \\
2 \\
2 \\
1 \\
2\end{array}$ & $\begin{array}{l}\overline{-} \\
\overline{2+} \\
-\end{array}$ & $\begin{array}{l}1+ \\
1+ \\
1+ \\
\frac{\operatorname{tr}}{}\end{array}$ & $\begin{array}{l}2 \\
2 \\
2 \\
1 \\
2\end{array}$ & $\begin{array}{l}\overline{-} \\
\overline{3+} \\
-\end{array}$ & $\begin{array}{l}2+ \\
2+ \\
3+ \\
\frac{3+}{3+}\end{array}$ & $\begin{array}{l}2 \\
2 \\
2 \\
1 \\
2\end{array}$ & $\begin{array}{l}1+ \\
3+ \\
\frac{1+}{3+} \\
3+\end{array}$ & $\begin{array}{l}4+ \\
3+ \\
2+ \\
2+ \\
2+\end{array}$ & $\begin{array}{l}2 \\
2 \\
2 \\
2 \\
2\end{array}$ & ฉ \\
\hline $\begin{array}{l}\text { A0294 } \\
\text { A0298 } \\
\text { A0301 } \\
\text { A0305 } \\
\text { A0307 }\end{array}$ & $\begin{array}{l}\overline{-} \\
3+ \\
-\end{array}$ & $\begin{array}{l}4+ \\
3+ \\
\operatorname{tr} \\
3+ \\
4+\end{array}$ & $\begin{array}{l}2 \\
2 \\
1 \\
2 \\
2\end{array}$ & $\begin{array}{l}\overline{-} \\
2+ \\
-\end{array}$ & $\begin{array}{l}1+ \\
2+ \\
\frac{1+}{2+} \\
2+\end{array}$ & $\begin{array}{l}2 \\
2 \\
1 \\
2 \\
2\end{array}$ & $\begin{array}{l}\frac{-}{2+} \\
=\end{array}$ & $\begin{array}{l}2+ \\
3+ \\
\frac{3+}{3+} \\
2+\end{array}$ & $\begin{array}{l}2 \\
2 \\
1 \\
2 \\
2\end{array}$ & $\begin{array}{l}3+ \\
4+ \\
4+ \\
4+ \\
4+\end{array}$ & $\begin{array}{l}\overline{4+} \\
\frac{4+}{-}\end{array}$ & $\begin{array}{l}1 \\
2 \\
1 \\
2 \\
1\end{array}$ & 产. \\
\hline $\begin{array}{l}\text { A0314 } \\
\text { A0323 } \\
\text { A0324 } \\
\text { A0327 } \\
\text { A0331 }\end{array}$ & $\begin{array}{l}z \\
z \\
-\end{array}$ & $\begin{array}{l}4+ \\
4+ \\
4+ \\
4+ \\
4+\end{array}$ & $\begin{array}{l}2 \\
2 \\
2 \\
2 \\
2\end{array}$ & $\begin{array}{l}- \\
\overline{-} \\
-\end{array}$ & $\begin{array}{l}1+ \\
1+ \\
1+ \\
2+ \\
1+\end{array}$ & $\begin{array}{l}2 \\
2 \\
2 \\
2 \\
2\end{array}$ & $\begin{array}{l}z \\
\overline{-} \\
-\end{array}$ & $\begin{array}{l}2+ \\
2+ \\
1+ \\
3+ \\
1+\end{array}$ & $\begin{array}{l}2 \\
2 \\
2 \\
2 \\
2\end{array}$ & $\begin{array}{l}2+ \\
3+ \\
3+ \\
4+ \\
3+\end{array}$ & $\begin{array}{l}1+ \\
2+ \\
1+ \\
3+ \\
-\end{array}$ & $\begin{array}{l}2 \\
2 \\
2 \\
2 \\
1\end{array}$ & \\
\hline $\begin{array}{l}\text { A0334 } \\
\text { A0335 } \\
\text { A0336 } \\
\text { A0338 } \\
\text { A0340 }\end{array}$ & $\begin{array}{l}- \\
\bar{z} \\
3+\end{array}$ & $\begin{array}{l}3+ \\
3+ \\
4+ \\
4+ \\
-\end{array}$ & $\begin{array}{l}2 \\
2 \\
2 \\
2 \\
1\end{array}$ & $\begin{array}{l}- \\
\overline{\operatorname{tr}} \\
2+\end{array}$ & $\begin{array}{l}1+ \\
1+ \\
2+ \\
1+ \\
\text { tr }\end{array}$ & $\begin{array}{l}2 \\
2 \\
2 \\
2 \\
1\end{array}$ & $\begin{array}{l}\overline{-} \\
\overline{4+}\end{array}$ & $\begin{array}{l}1+ \\
2+ \\
\frac{3+}{-}\end{array}$ & $\begin{array}{l}2 \\
2 \\
+ \\
2 \\
1\end{array}$ & $\begin{array}{l}1+ \\
3+ \\
\frac{4+}{1+} \\
1+\end{array}$ & $\begin{array}{l}1+ \\
3+ \\
2+ \\
2+ \\
-\end{array}$ & $\begin{array}{l}2 \\
2 \\
2 \\
2 \\
1\end{array}$ & \\
\hline $\begin{array}{l}\text { A0343 } \\
\text { A0347 } \\
\text { A0358 } \\
\text { A0363 } \\
\text { A0368 }\end{array}$ & $\begin{array}{l}- \\
3+ \\
2+ \\
2+ \\
-\end{array}$ & $\frac{\frac{3+}{1+}}{\frac{1}{2+}}$ & $\begin{array}{l}2 \\
1 \\
\dagger \\
1 \\
2\end{array}$ & $\begin{array}{l}2+ \\
2+ \\
2+ \\
3+ \\
-\end{array}$ & $\begin{array}{l}\frac{1+}{-} \\
\frac{1}{1+}\end{array}$ & $\begin{array}{l}\dagger \\
1 \\
1 \\
1 \\
2\end{array}$ & $\begin{array}{l}\text { NT } \\
3+ \\
3+ \\
-\end{array}$ & $\frac{\mathrm{NT}}{\frac{\operatorname{tr}}{3+}}$ & $\begin{array}{l}- \\
1 \\
1 \\
1 \\
2\end{array}$ & $\begin{array}{l}1+ \\
1+ \\
4+ \\
1+ \\
-\end{array}$ & $\begin{array}{l}3+ \\
\frac{1+}{1+}\end{array}$ & $\begin{array}{l}2 \\
1 \\
1 \\
2 \\
\dagger\end{array}$ & \\
\hline $\begin{array}{l}\text { A0370 } \\
\text { A0376 } \\
\text { A0386 } \\
\text { A0392 } \\
\text { A0402 }\end{array}$ & $\begin{array}{l}2+ \\
= \\
=\end{array}$ & $\begin{array}{l}\text { tr } \\
4+ \\
4+ \\
3+ \\
4+\end{array}$ & $\begin{array}{l}1 \\
2 \\
2 \\
2 \\
2\end{array}$ & $\frac{3+}{\frac{-}{\operatorname{tr}}}$ & $\begin{array}{l}-2+ \\
1+ \\
1+ \\
1+\end{array}$ & $\begin{array}{l}1 \\
2 \\
2 \\
2 \\
2\end{array}$ & $\begin{array}{l}\frac{3+}{1+} \\
\frac{1+}{-}\end{array}$ & $\begin{array}{l}\overline{3+} \\
2+ \\
2+ \\
3+\end{array}$ & $\begin{array}{l}1 \\
2 \\
2 \\
2 \\
2\end{array}$ & $\begin{array}{l}2+ \\
2+ \\
2+ \\
4+ \\
2+\end{array}$ & $\begin{array}{l}2+ \\
3+ \\
1+ \\
4+ \\
-\end{array}$ & $\begin{array}{l}2 \\
2 \\
2 \\
2 \\
1\end{array}$ & \\
\hline $\begin{array}{l}\text { A0434 } \\
\text { A0457 }\end{array}$ & - & $\begin{array}{l}4+ \\
3+\end{array}$ & $\begin{array}{l}2 \\
2\end{array}$ & 二 & $\begin{array}{l}1+ \\
1+\end{array}$ & $\begin{array}{l}2 \\
2\end{array}$ & - & $\overline{3+}$ & $\begin{array}{l}t \\
2\end{array}$ & $\begin{array}{l}2+ \\
2+\end{array}$ & $\begin{array}{l}2+ \\
2+\end{array}$ & $\begin{array}{l}2 \\
2\end{array}$ & \\
\hline
\end{tabular}

"All " $A$ " numbers are clinical isolates.

†Untypable.

Stain intensity: tr, trace; $1+, 25 \%$ of maximum; $2+, 50 \%$ of maximum; $3+, 75 \%$ of maximum; $4+$, maximum.

$\mathrm{NT}=$ not tested. 
Table 2 Serotyping reaction patterns of herpes simplex virus isolates using the avidin-biotin complex $(A B C)$ method and three commercial immunofuorescence kits. Figures are numbers of isolates

\begin{tabular}{|c|c|c|c|c|}
\hline Reaction pattern ${ }^{*}$ & $A B C$ stain & Immulok & Syva & Electro-Nucleonics \\
\hline $\begin{array}{l}\text { Type } 2+\}(-+) \\
\text { Type } 1(+-) \\
\text { Untypable }(++) \\
\text { Untypable }(+-) \\
\text { Not tested } \\
\text { Total }\end{array}$ & $\begin{array}{r}43 \\
8 \\
1 \\
0 \\
0 \\
52\end{array}$ & $\begin{array}{r}42 \\
9 \\
1 \\
0 \\
0 \\
52\end{array}$ & $\begin{array}{r}36 \\
8 \\
0 \\
6 \\
2 \\
52\end{array}$ & $\begin{array}{c}6 \\
32 \\
13 \\
\text { NA } \\
1 \\
0 \\
52\end{array}$ \\
\hline
\end{tabular}

${ }^{*}$ Reaction pattern designates staining with (type 1 antibody, type 2 antibody).

+ Both $(-+)$ and $(++)$ reaction patterns apply for the type 2 isolates detected by the Electro-Nucleonics method.

$\ddagger$ Reaction pattern $(++)$ is not an untypable pattern in the Electro-Nucleonics test, hence it does not apply as an untypable result (NA $=$ not applicable) .

compared with the avidin-biotin complex method (Table 3). The Immulok and Electro-Nucleonics reagents were similar to the avidin-biotin complex reagents in detecting the presence of herpes simplex virus antigen in infected cells, whereas the Syva reagents missed the six strains as noted above.

Table 4 shows the predictive values of the immunofluorescence tests compared with the avidin-biotin complex method. These values are a measure of the ability of the test to identify correctly the serotype of the isolate. It can be seen from these values that the Electro-Nucleonics reagents were not reliable in identifying the serotype of the isolate.

Table 3 Sensitivity of three immunofuorescence kits for detecting herpes simplex virus in infected cultures

\begin{tabular}{lrll}
\hline Test result & \multicolumn{2}{c}{$A B C$} & Sensitivity (\%) \\
\cline { 2 - 3 } & + & - & \\
\hline Immulok & 52 & 0 & 100 \\
+ & 0 & 0 & \\
- & 44 & 0 & 88 \\
Syva & 6 & 0 & \\
+ & 51 & 0 & 98 \\
Electro-Nucleonics & 1 & 0 & 98 \\
+ & &
\end{tabular}

$\mathrm{ABC}=$ avidin-biotin complex.

$+=$ positive; $-=$ negative.
There was excellent agreement among the avidinbiotin complex, Immulok, and Syva methods in identifying type $2 \mathrm{HSV}$ and good agreement in identifying type $1 \mathrm{HSV}$.

\section{Discussion}

The results of this study indicate that the avidinbiotin complex method of staining is comparable in sensitivity to some of the commercially available immunofluorescence kits. The avidin-biotin complex method also gave similar predictive values. One of those kits (Syva) lacked sensitivity compared with the other methods tested, as evidenced by its inability to identify six of the isolates. This is probably a result of a too restrictive epitope range of the monoclonal antibody or antibody cocktail provided with the kit. Another kit (Electro-Nucleonics) lacked specificity in our hands. When compared with the other methods tested, it typed 11 isolates incorrectly. In addition, the stain produced by the reagents used in the Electro-Nucleonics kit was weak in some instances. As a result, it was difficult to interpret the results, and this was probably one of the causes of the faulty typing associated with the use of this kit.

We performed additional experiments to determine if the avidin-biotin complex method could be

Table 4 Predictive values of three immunoftuorescence tests for correctly serotyping herpes simplex virus isolates using the avidin-biotin complex system $(A B C)$ as the standard

\begin{tabular}{|c|c|c|c|c|}
\hline \multirow[t]{2}{*}{ Test result } & \multicolumn{3}{|l|}{$A B C$} & \multirow[t]{2}{*}{ Predictive value (\%) } \\
\hline & Type 1 & Type 2 & Untypable & \\
\hline $\begin{array}{c}\text { Immulok } \\
\text { Type } 1 \\
\text { Type } 2 \\
\text { Untypable } \\
\text { Syva }\end{array}$ & $\begin{array}{l}8 \\
0 \\
0\end{array}$ & $\begin{array}{r}0 \\
42 \\
1\end{array}$ & $\begin{array}{l}1 \\
0 \\
0\end{array}$ & $\begin{array}{r}89 \\
100\end{array}$ \\
\hline $\begin{array}{l}\text { Type } 1 \\
\text { Type } 2 \\
\text { Untypable } \\
\text { Electro-Nucle }\end{array}$ & $\begin{array}{l}7 \\
0 \\
1\end{array}$ & $\begin{array}{r}0 \\
36 \\
5\end{array}$ & $\begin{array}{l}1 \\
0 \\
0\end{array}$ & $\begin{array}{r}88 \\
100\end{array}$ \\
\hline $\begin{array}{l}\text { Type } 1 \\
\text { Type } 2 \\
\text { Untypable } \\
\end{array}$ & $\begin{array}{l}5 \\
3 \\
0\end{array}$ & $\begin{array}{r}8 \\
34 \\
1\end{array}$ & $\begin{array}{l}1 \\
1 \\
0\end{array}$ & $\begin{array}{l}36 \\
89\end{array}$ \\
\hline
\end{tabular}


used reliably to detect herpes simplex virus infection in cell culture 24 hours or more after infection with either small amounts of HSV 2 strain 333 virus, McIntyre type 1 strain, or clinical strains in diagnostic specimens. We found that as little as $1-3$ plaque forming units could be detected 24 hours after infection, but success was dependent on the formation of cytopathic effects. Testing clinical specimens 24 hours after infection lead to extreme difficulties in interpretation because of non-specific staining in negative cultures. We found that if viral cytopathic effects were present, particularly when localised in discreet foci, the avidin-biotin complex stain gave useful confirmatory results. When no cytopathic effects were evident, however, the avidin-biotin complex stain could not be reliably used to detect infected cells. In addition, we used the avidin-biotin complex stain to serotype virus isolated directly from patient specimens with no intervening virus subcultures. In these experiments each specimen was divided into two isolation tubes. Negative cultures showed the typical amount of background stain, whereas the cultures showing cytopathic effects were intensely stained with one or other monoclonal reagents. We serotyped more than 40 such isolates with clear results. Thus the avidinbiotin complex stain worked well as a serotyping system under the laboratory conditions used in isolating herpes simplex virus from patient material and where the presence of virus is known from the evidence of cytopathic effects.

The avidin-biotin complex method offers an alternative to immunofluorescence to those laboratories wishing to serotype herpes simplex virus isolates without using a fluorescence microscope. Similar caution must, however, be exercised in interpreting the staining results, and positive and negative controls must always be included.

This study was supported in part by the John W Adkins Memorial Virus Research Fund.

\section{References}

' Zheng ZM, Mayo DR, Hsiung GD. Comparison of biological, biochemical, immunological, and immunochemical techniques for typing herpes simplex virus isolates. J Clin Microbiol 1983;17:396-9.

${ }^{2}$ Geder L, Skinner GRB. Differentiation between type 1 and type 2 strains of herpes simplex virus by an indirect immunofluorescent technique. J Gen Virol 1971;12:179-82.

${ }^{3}$ Schmidt NJ, Dennis J, Devlin V, Gallo D, Mills J. Comparison of direct immunofluorescence and direct immunoperoxidase procedures for detection of herpes simplex virus antigen in lesion specimens. J Clin Microbiol 1983;18:445-8.

${ }^{4}$ Moseley RC, Corey L, Benjamin D, Winter C, Remington ML. Comparison of viral isolation, direct immunofluorescence, and indirect immunoperoxidase techniques for detection of genital herpes simplex virus infection. J Clin Microbiol 1981; 13:913-8.

${ }^{5}$ Gerna G, Battaglia M, Revello MG, Gerna MT. Typing of herpes simplex virus isolates by enzyme-linked immunosorbent assay: comparison between indirect and double-antibody sandwich techniques. J Clin Microbiol 1983;17:942-4.

- Land S-A, Skurrie IJ, Gilbert GL. Rapid diagnosis of herpes simplex virus infections by enzyme-linked immunosorbent assay. J Clin Microbiol 1984; 19:865-9.

' Adler-Storthz K, Kendall C, Kennedy RC, Henkel RD, Dreesman GR. Biotin-avidin-amplified enzyme immunoassay for detection of herpes simplex virus antigen in clinical specimens. J Clin Microbiol 1983;18:1329-34.

${ }^{8}$ Morgan MA, Smith TF. Evaluation of an enzyme-linked immunosorbent assay for the detection of herpes simplex virus antigen.J Clin Microbiol 1984;19:730-2.

" Yolken RH, Stopa PJ. Enzyme-linked fluorescence assay: ultrasensitive solid-phase assay for detection of human rotavirus. J Clin Microbiol 1979;10:317-21.

${ }^{10}$ Pronovost AD, Baumgarten A, Hsiung GD. Sensitive chemiluminescent enzyme-linked immunosorbent assay for quantification of human immunoglobulin $\mathrm{G}$ and detection of herpes simplex virus.J Clin Microbiol 1981;13:97-101.

" Kendall C, Ionescu-Matiu I, Dreesman GR. Utilization of the biotin/avidin system to amplify the sensitivity of the enzymelinked immunosorbent assay (ELISA). J Immunol Methods 1983; 56:329-39.

12 Yolken RH, Leister FJ, Whitcomb LS, Santosham M. Enzyme immunoassays for the detection of bacterial antigens utilizing biotin-labeled antibody and peroxidase biotin-avidin complex. J Immunol Methods 1983;56:319-27.

${ }^{13}$ Smith KJ, Ashley CR, Darvill JM, Harbour J, Roome A. Com parison of a commercial ELISA system with restrictiof endonuclease analyses for typing herpes simplex virus. J Clim Pathol 1984;37:937-41.

${ }^{14}$ Brautigam AR, Richman DD, Oxman MN. Rapid typing of herpes simplex virus isolates by deoxyribonucleic acid: deoxyribonucleic acid hybridization. J Clin Microbiol 1980;12:226-34.

is Green NM. Avidin. Adv Protein Chem 1975;29:85-133.

${ }^{16}$ Guesdon J, Ternynck T, Avrameas S. The use of avidin-biotin interaction in immunoenzymatic techniques. $J$ Histochem Cytochem 1979; 27:1131-9.

${ }^{17}$ Hsu S-M, Raine L, Fanger H. Use of avidin-biotin-peroxidase complex $(A B C)$ in immunoperoxidase techniques: a comparison between ABC and unlabelled antibody (PAP) procedures. J Histochem Cytochem 1981;29:577-80.

${ }^{18} \mathrm{Hsu}$ S-M, Raine L, Fanger H. A comparative study of the peroxidase-anti-peroxidase method and an avidin-biotin complex method for studying polypeptide hormones with radioimmunoassay antibodies. Am J Clin Pathol 1981; 75:734-8.

19 Bergroth V. Comparison of various immunohistochemical methods. Histocytochemistry 1983;77:177-84.

${ }^{20}$ Johnson FB, Leavitt RW, Richards DF. Evaluation of the virocult transport tube for isolation of herpes simplex virus from clinical specimens. J Clin Microbiol 1984;20:120-2.

${ }^{21}$ Johnson FB, Leavitt RW, Richards DF. Comparison of the Scott Selecticult-HSV kit with conventional culture and direct immunoperoxidase staining for detection of herpes simplex $\mathrm{N}$ virus in cultures of clinical specimens. $J$ Clin Microbiol 1985; 21:438-41.

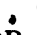

Requests for reprints to: Dr F Brent Johnson, $887 \mathrm{~W} 1 \mathrm{DB}, \stackrel{\oplus}{\mathscr{Q}}$ Department of Microbiology, Brigham Young University, $\stackrel{\infty}{?}$ Provo, Utah 84602, USA. 